\title{
Reflections on Nimble Tongues
}

\author{
S.G. Kellman \\ University of Texas at San Antonio, USA \\ 1 UTSA Circle, San Antonio, TX 78249
}

Article history:

Received: 17.09.2020

Accepted: 14.10.2020

Moderator: O.A. Valikova

Conflict of interests: none

For citation:

Kellman, S.G. 2020. "Reflections on Nimble Tongues". Polylinguality and Transcultural Practices, 17 (4), 562-565. DOI 10.22363/2618-897X-2020-17-4-562-565

\section{Размышления о книге Nimble Tongues}

\author{
С.Г. Келлман \\ Техасский университет Сан-Антонио, США \\ 1 Университетский округ, ТХ 78249
}

\section{История статьи:}

Дата поступления в редакцию: 17.09.2020

Дата принятия к печати: 14.10.2020

Модератор: О.А. Валикова

Конфликт интересов: отсутствует

\section{Для цитирования:}

Келлман С.Г. Размышления о книге Nimble Tongues // Полилингвиальность и транскультурные практики. 2020. Т. 17. № 4. C. 562-565. DOI 10.22363/2618-897X-2020-17-4-562-565

(с) Келлман С.Г., 2020

(C) (i) This work is licensed under a Creative Commons Attribution 4.0 International License https://creativecommons.org/licenses/by/4.0/ 
Joseph Conrad wrote remarkable fiction not in his native Polish or even his second language, French, but in English, a language he began studying seriously only after settling in England while in his twenties. Conrad likened his literary translingualism to arduous, dangerous labor. "I had to work like a coal-miner in his pit quarrying all my English sentences out of a black night", he explained. The achievements of Conrad, Samuel Beckett, Vladimir Nabokov, and hundreds of other translingual authors inspired me to become a literary mineralogist, studying the ore - more precious than coal - that they have mined. In The Translingual Imagination (University of Nebraska Press, 2000), I offered a synoptic overview of the phenomenon. In Switching Languages: Translingual Writers Reflect on Their Craft (University of Nebraska Press, 2003), I collected statements on language by numerous authors who have used an adopted language as their literary medium. Nimble Tongues: Studies in Literary Translingualism (Purdue University Press, 2020) now offers further general thoughts on the phenomenon as well as case studies in particular examples of what Yoko Tawada, who writes in her native Japanese as well as German, prefers to call exophony.

The volume begins by posing the fundamental question: "Does translingualism matter?" For the Puerto Rican novelist Rosario Ferré, it very much mattered each time she made a choice between Spanish and English. For her, "a bilingual writer is really two different writers, has two very different voices, writes in two different styles, and, most important, looks at the world through two different sets of glasses". So it follows that a Ferré novel written in English is very different from one written in Spanish. However, the Indian novelist Raja Rao dismissed the whole subject as insignificant. "The important thing", he contended, in English, not his native Kannada, "is not what language one writes in, for language is really an accidental thing. What matters is the authenticity of experience, and this can generally be achieved in any language".

Nevertheless, many bilingual writers portray themselves as - often painfully suspended between mutually exclusive worlds. For much of her 1989 memoir, appropriately titled Lost in Translation, Eva Hoffman describes her native Polish slipping away before she has acquired the fluency in English to be fully articulate in that language either. Employing the metaphor of home to describe their relationship to language (though he lives in Spain, Swiss novelist Martin Suter considers the German language his home: "Heimat ist für mich meine Sprache"), some writers seem homeless. J.M. Coetzee, who grew up speaking Afrikaans and English, mastered the latter well enough to have earned the Nobel Prize in Literature by using it as his medium. Nevertheless, he told an audience in India that the language he writes in, English, is not his home: "As a child in South Africa, I was sent to an English medium school because my parents thought it was a way to the future. I then studied in English at the university level. Yet I can't say that I can feel at home in English. I feel I am writing in someone else's language”.

Nimble Tongues moves from these and other general reflections - on subjects including the eroticism of language and the treason of translation - to an examination of the fascinating case of the Chilean-American author Ariel Dorfman and the profound changes introduced into his 1998 memoir Heading South, Looking North when, a few months later, he rewrote it in Spanish as Rumbo al Sur, deseando el Norte. The book also examines the career of Francesca Marciano, a native of Italy who has written dozens of screenplays in Italian but writes all of her books in English. Marciano's linguistic counterpart is Jhumpa 
Lahiri, who - despite notable success writing fiction in English, her second language, after Bengali - fell in love with Italian, a language she had no prior connection with, and abandoned English to write in it. Even odder is the case of Hugo Hamilton, who was born in Dublin to a German-speaking mother and an Irish-speaking father. Fanatically devoted to Irish cultural independence, Hamilton's father forbade his children from speaking English in their home. However, Hamilton grew up to be a formidable English-language author. But perhaps the most bizarre example of translingualism examined in Nimble Tongues is Incubus, a 1965 horror film that is the only feature-length motion picture made in Esperanto, the constructed international auxiliary language that is the native tongue of almost no one. It was certainly foreign to the film's cast and crew, and their exclusive use of Esperanto delivers an additional frisson while defamiliarizing the common tropes of its movie genre.

The final two chapters of Nimble Tongues go beyond literary and cinematic translingualism to larger cultural and political issues. A discussion of linguaphobia analyzes the pervasive fear and mistrust of other languages, i.e., languages of The Other. In the United States in particular, hostility toward the use of any language but English has increased dramatically and alarmingly in recent years, even though the nation has been multilingual since its inception and Spanish, Chinese, Tagalog, Vietnamese, Arabic, French, Korean, Russian, German, and hundreds of other languages continue to be widely spoken.

The book concludes with reflections on the Universal Declaration of Human Rights, a statement of ideals adopted by the United Nations General Assembly in 1948 in reaction to the atrocities of World War II. Said to be the most widely translated document, the Universal Declaration now exists in more than 500 linguistic versions. However, each linguistic rendition is supposed to be equally valid; the rights enshrined in ithe UDHR are meant to be absolute, independent of their embodiment in any particular language and applicable to speakers of any tongue. It is supposed to be irrelevant whether they are read in Abkhaz or Zulu. Nevertheless, as any student of translingual literature should realize, each language embodies its own Weltanschaaung; the meaning is never precisely the same when transposing from one language to another. Aside from the question argued heatedly by lawyers, politicians, and anthropologists - of whether rights are genuinely universal, the very meaning of the word rights - like that of other key words throughout the UDHR - has only approximate equivalents in other languages. the English word right does not translate perfectly into the Russian право (prava) the Chinese 權 (quán), or the Hindi सही (sahī). The Greek word (zkhuyot), the Hebrew word, lack any authoritative association with the dominant right hand found in the words rights, droits, derechos, and Rechte.

Thus, Nimble Tongues ends, appropriately, on a note of caution. Just as the translingual project is doomed to imperfect approximation, so, too, is its study. No one scholar possesses the linguistic equipment to take on alone the task of exhausting the rich variety of translingual expression. If there are approximately 5,000 languages in the world, the number of translingual possibilities would equal $5,000 \times 4,999 \div 2=12,497,500$. And that is only calculating the number of bilingual translingual possibilities; authors who, like Kamala Das, Vladimir Nabokov, and George Steiner, move among three or more languages add even more possibilities to the challenge of mapping out the universe of translingual literature. Nimble Tongues is my humble contribution to the collective effort. 


\section{Bio Note:}

S.G. Kellman is a Professor at the Department of English, University of Texas at San Antonio, USA. E-mail: steven.kellman@utsa.edu

\section{Сведения об авторе:}

Келлман Стивен - профессор Департамента английского языка Техасского университета Сан-Антонио, США. E-mail: steven.kellman@utsa.edu 